Article

\title{
Natural Extracts from White Common Bean (Phaseolus vulgaris L.) Inhibit 3T3-L1 Adipocytes Differentiation
}

\author{
Zhenxing Shi ${ }^{1,2,+} \oplus$, Xin Zhang ${ }^{3,+}$, Yingying Zhu ${ }^{4}$, Yang Yao ${ }^{1, *}$ and Guixing Ren ${ }^{1}$ \\ 1 Institute of Crop Science, Chinese Academy of Agricultural Sciences (CAAS), 80 South Xueyuan Road, \\ Haidian, Beijing 100081, China; shizhenxing@caas.cn (Z.S.); renguixing@caas.cn (G.R.) \\ 2 Gastronomic Sciences Lab, University of Liege-Gembloux Agri-Bio Tech, Passage des Déportés, \\ 5030 Gembloux, Belgium \\ 3 College of Artificial Intelligence and Electrical Engineering, Gui Zhou Institute of Technology, \\ 1 Caiguan Road, Yunyan, Guiyang 550003, Guizhou, China; gami_zx@126.com \\ 4 School of Food and Biological Engineering, Zhengzhou University of Light Industry, No. 166 Kexue Road, \\ Zhengzhou 450002, Henan, China; zhuying881020@163.com \\ * Correspondence: yaoyang@caas.cn; Tel.: +86-10-6211-5596; Fax: +86-10-6215-6596 \\ + The first two authors contribute equally to this work.
}

Citation: Shi, Z.; Zhang, X.; Zhu, Y.; Yao, Y.; Ren, G. Natural Extracts from White Common Bean (Phaseolus vulgaris L.) Inhibit 3T3-L1 Adipocytes Differentiation. Appl. Sci. 2021, 11, 167. https://dx.doi.org/10.3390/ app11010167

Received: 9 December 2020

Accepted: 22 December 2020

Published: 26 December 2020

Publisher's Note: MDPI stays neutral with regard to jurisdictional claims in published maps and institutional affiliations.

Copyright: () 2020 by the authors. Licensee MDPI, Basel, Switzerland. This article is an open access article distributed under the terms and conditions of the Creative Commons Attribution (CC BY) license (https: / / creativecommons.org/ licenses/by/4.0/).
Abstract: Background: Recent studies have shown that the consumption of common bean (Phaseolus vulgaris L.) foods plays an essential role in the prevention and treatment of obesity. Methods: In this study, different natural extracts that include common bean polyphenol-rich extract (CBP), $\alpha$-amylase inhibitor-rich extract ( $\alpha$-AIE), and non-starch polysaccharides-rich extract (NSP) were isolated. Their effects on 3T3-L1 adipocytes differentiation were evaluated, respectively. Results: The results showed that CPB reduced the lipid content in the mature adipocytes to $79.29 \%(150 \mu \mathrm{g} / \mathrm{mL})$ and $35.13 \%$ (300 $\mu \mathrm{g} / \mathrm{mL})$, and $\alpha$-AIE reduced it to $90.20 \%(2 \mathrm{mg} / \mathrm{mL})$ and $68.28 \%(4 \mathrm{mg} / \mathrm{mL})$, while NSP exhibited an auxo-action, suggesting that both CBP and a-AIE inhibited 3T3-L1 adipocytes differentiation. Additionally, CBP significantly suppressed $(p<0.05)$ the mRNA expression level and the protein expression level of peroxisome proliferator-activated receptor $\gamma(\operatorname{PPAR} \gamma)$, CCAAT-enhancer-binding protein $\alpha(\mathrm{C} / \mathrm{EBP} \alpha)$, sterol-regulatory element binding proteins $1 \mathrm{c}(\mathrm{SREBP}-1 \mathrm{c})$, lipoprotein lipase (LPL), and fatty acid binding protein (ap2). Meanwhile, $\alpha$-AIE only showed significant suppression effects on PPAR $\gamma, \mathrm{C} / \mathrm{EBP} \alpha$, and ap2 at the high dose of $4 \mathrm{mg} / \mathrm{mL}(p<0.05)$. Conclusions: These findings indicate that $\mathrm{CBP}$, from white common bean, might be the major component responsible for the inhibitory effects on adipocyte differentiation.

Keywords: common bean; polyphenol; $\alpha$-amylase inhibitor; non-starch polysaccharides; 3T3-L1

\section{Introduction}

In recent years, obesity has dramatically increased and become a worldwide public health concern [1]. To date, more than $30 \%$ of adults across the world are overweight, and almost $10 \%$ of adults are obese [2]. In China, it is reported that the rates of overweight and obesity have reached $23.7 \%$ among Chinese children and $17.6 \%$ among Chinese adolescents in 2015 [3]. Obesity is related with an increased occurrence of various chronic metabolic diseases, such as cancer, type 2 diabetes, and cardiovascular disease, which even decreases 5-20 years of life depending on the severity of the condition and comorbid disorder [4]. A major and direct characteristic involved in obesity is the hypertrophy of pre-existing adipocytes and an increased deposition of cytoplasmic triglycerides during pre-adipocyte differentiation into mature adipocytes [5,6]. Previous studies suggested that several transcription factors, mainly peroxisome-proliferator-activated receptor families (PPAR) and CCAAT/enhancer binding protein (C/EBP) families, will promote adipocyte differentiation [7-9]. Accordingly, it is helpful to understand the mechanisms of specific nutrients that affect adipocyte differentiation in the prevention of obesity and treatment of the associated diseases. 
Increasing interests have focused on the use of natural extracts from plants as an alternative approach for the treatment of obesity. It is reported that many natural agents, such as polyphenol, glycoprotein, plant-derived peptides, and polysaccharides, exert antiobesity effects by inhibiting adipocyte differentiation [10-13]. Common bean (Phaseolus vulgaris L.) is one of the traditional food legumes in Africa and South America, and it has attracted worldwide attention owing to its well-documented anti-obesity activity [14-16]. A series of bioactive compounds that include $\alpha$-amylase inhibitor glycinin ( $\alpha$-AI), polyphenol, flavonoid, and dietary fiber (resistant starch, non-starch polysaccharide) has been discovered as the bioactive components in common bean $[17,18]$. At present, $\alpha-\mathrm{AI}$ is the mostly focused component responsible for the anti-obesity effects of common bean foods. $\alpha$-AI is able to inhibit saliva and pancreatic amylase, hinder the hydrolysis of starch in food, decrease the digestion of major carbohydrates, and modulate the gut microbiota composition in vivo, so it can be used to restrain fat synthesis without side effects $[19,20]$. However, as a glycoprotein, limited research studies have focused on the effects of $\alpha$-AI on the adipocyte differentiation. Additionally, polyphenols from various plants and non-starch polysaccharides-rich extract (NSP) from cereals have been confirmed to inhibit adipocyte differentiation in vitro by the downregulation of three key transcription factors which include $\operatorname{PPAR} \gamma, \mathrm{C} / \mathrm{EBP} \alpha$, and sterol-regulatory element binding proteins 1 c (SREBP-1c) [13,21-23]. Whether the NSP and polyphenol extracted from common bean could suppress the differentiation of adipocyte remains to be studied. 3T3-L1 cells are well-known models for evaluating the inhibition effect of bioactivity compounds on preadipocyte differentiation or lipid metabolism [13,24,25].

Consequently, in the present study, we aimed to compare the inhibitory effects of different natural extracts from white common bean on 3T3-L1 adipocyte differentiation, thus providing a new insight into the anti-obesity effects of common bean foods. Based on this purpose, we firstly isolated different natural extracts, including polyphenols-rich extract $(\mathrm{CBP}), \alpha$-amylase inhibitor (AI)-rich extract ( $\alpha$-AIE), and NSP from white common bean seeds. Then, their suppressive effects on 3T3-L1 adipocyte differentiation were evaluated. At last, the effects on the PPAR $\gamma$ signaling pathway were further investigated.

\section{Material and Method}

\subsection{Chemicals}

Insulin, 1-methyl-3-isobutylxanthine (IBMX), dexamethasone (DEX), Dulbecco's modified eagle's medium (DMEM), fetal bovine serum (FBS), dimethyl sulfoxide (DMSO), and methylene blue were provided by Sigma Chemical Co. (St. Louis, MO, USA). Other analytical grade chemicals were purchased from Tianjinfangzheng Chemical Co. (Tianjin, China).

\subsection{Materials}

3T3-L1 pre-adipocytes were provided by the Institutes of Biological Sciences of Chinese Academy of Sciences (Shanghai, China). White common bean seeds (Cultivar Longquanjiuli) were provided by the Pinzhen food Co. (Haerbin, China).

CBP was extracted according to the preliminary studies in our lab. Briefly, common bean flour was mixed with $70 \%$ ethanol $(w / v=1: 10)$ and stirred for $2 \mathrm{~h}$ at room temperature. The supernatants were concentrated at $50{ }^{\circ} \mathrm{C}$ after vacuum filtration. Then, the concentrated supernatants were freeze-dried, and a CBP sample was obtained [26]. The total polyphenol content (TPC) by the Folin-Ciocalteu method withGallic Acid Equivalent(GAE), and phenols composition of CBP were determined by High-Performance Liquid Chromatography (HPLC) according to the method of Shi et al. and Yao et al. [26,27].

$\alpha$-AIE were prepared according to a reported method [28]. Briefly, common bean powder was suspended in distilled water $(1: 10 \mathrm{w} / \mathrm{v})$. The mixture was stirred for $2 \mathrm{~h}$ at room temperature and then was centrifuged $(12,000 \mathrm{rpm}, 1 \mathrm{~h})$, and the supernatants were put into a water bath kettle $\left(70{ }^{\circ} \mathrm{C}, 20 \mathrm{~min}\right)$. After the addition of $30 \%$ ammonium sulfate and tert-butanol, the lower layer was collected. A GE Sephax G-75 column (Chicago, IL, USA) was used to remove the salt. The total protein content in $\alpha$-AIE was determined by 
a BCA protein assay kit (Sigma Co, St. Louis, MO, USA). The $\alpha$-amylase inhibition activity was evaluated by a preliminary method in our lab [29].

NSP was extracted from defatted white common bean flour with hot water $(1: 20 \mathrm{w} / \mathrm{v}$, $90{ }^{\circ} \mathrm{C}, 4 \mathrm{~h}$ ). The starch and protein in the supernatants was respectively removed by $\alpha$-amylase and by the Sevag method [30]. The quadrupled volume of ethanol was added into the supernatants to precipitate the polysaccharides; after standing for $12 \mathrm{~h}$ at $4{ }^{\circ} \mathrm{C}$, the sediments were collected. The crude NSP was further purified by an ÄKTA explorer 100 purification system as reported by Yao et al. [31]. The purity was determined by the 3,5-dinitrosalicylic acid (DNS) method, and the molecular weight distribution of NSP were analyzed by a multi-angle laser light scattering and refractive index (HPSEC-MALLS-RID) system [31].

\subsection{Cell Cultures}

For the 3T3-L1 pre-adipocytes, 10\% FBS, 1\% penicillin, and 1\% streptomycin were added to the DMEM and cultured in a humidified atmosphere $\left(37^{\circ} \mathrm{C}, 5 \% \mathrm{CO}_{2}\right)$.

\subsection{Cell Cytotoxicity Assay}

The cytotoxicity was evaluated by a reported method [32] with the concentrations for CBP $(0-300 \mu \mathrm{g} / \mathrm{mL})$, NSP $(0-4 \mathrm{mg} / \mathrm{mL})$, and $\alpha$-AIE $(0-4 \mathrm{mg} / \mathrm{mL})$ or DMEM medium. Three wells were used for each condition and values are average of three replicates.

\subsection{T3-L1 Adipocyte Differentiation}

The method of Zhu et al. was used to evaluate the inhibition of CBP, $\alpha$-AIE, and NSP on the 3T3-L1 adipocyte differentiation following the two steps [13]. Step 1: 3T3-L1 pre-adipocytes were firstly cultured in DMEM containing 10\% FBS, $1 \%$ penicillin, and $1 \%$ streptomycin until fusion. Then, differentiation medium I ( $0.1 \mu \mathrm{M}$ DEX, $0.5 \mathrm{mM} \mathrm{IBMX}$, and $10 \mu \mathrm{g} / \mathrm{mL}$ insulin in DMEM) was added to replace the basic medium, and it was cultured for $48 \mathrm{~h}$. Step 2: The differentiation medium II ( $5 \mu \mathrm{g} / \mathrm{mL}$ insulin in DMEM) was added to replace the medium I and cultured for additional $48 \mathrm{~h}$. Finally, medium II was replaced with DMEM containing CBP $(150 \mu \mathrm{g} / \mathrm{mL}$ or $300 \mu \mathrm{g} / \mathrm{mL}), \alpha$-AIE $(2 \mathrm{mg} / \mathrm{mL}$ or $4 \mathrm{mg} / \mathrm{mL})$, or NSP $(2 \mathrm{mg} / \mathrm{mL}$ or $4 \mathrm{mg} / \mathrm{mL})$, and continued culture for $24 \mathrm{~h}$. During the experiments, three wells were used for each condition, and the values are average of three replicates.

\subsection{Oil Red O Staining}

The Oil Red O Kit (Solabio Life science, Beijing, China.) was used to stain 3T3-L1 cells. An Olympus (Tokyo, Japan) microscope was used to capture Images. Then, isopropanol was added to extract the stained Oil Red O. A microplate reader (Bio-Rad, Richmond, Hercules, MA, USA) was used to determine the OD absorbance $(492 \mathrm{~nm})$. The final values are the average of three replicates.

\section{7. mRNA Expression Analysis}

Tizol Reagent (Invitrogen, Carslbad, CA, USA) and the High Capacity cDNA Reverse Transcription kit (Applied Biosystems, Foster City, CA, USA) were used to extract the total mRNA and to generate the Complementary DNA (cDNA), respectively. The mRNA expression level of PPAR $\gamma, \mathrm{C} / \mathrm{EBP} \alpha$, SREBP1c, lipoprotein lipase (LPL), and fatty acid binding protein (ap2) was analyzed by a 7300 Real Time PCR (RT-PCR) System (Applied Biosystems, Foster City, CA, USA). The gene sequence of each primer was listed in Table 1, and the $\beta$-Actin gene was used as an internal standard gene. The relative amount of each gene was calculated using the 2-( $\Delta \Delta \mathrm{Ct})$ method [33]. Analysis was carried out in triplicate.

\subsection{Protein Analysis}

The protein expression level of PPAR $\gamma, \mathrm{C} / \mathrm{EBP} \alpha, \mathrm{SREBP} 1 \mathrm{c}, \mathrm{LPL}$, and ap2 was evaluated by the Western blot analysis as reported by a previous study [13]. The anti-PPAR $\gamma$, $\mathrm{C} / \mathrm{EBP} \alpha, \mathrm{SREBP}-1 \mathrm{c}$, ap2, LPL, $\beta$-actin antibody, and Horseradish Peroxidase (HRP)-conjugated 
secondary antibody were provided by Proteintech Group (Chicago, IL, USA). The Super Signal ELISA Pico Chemiluminescent Substrate (Thermo Fisher Scientific, Waltham, MA, USA) was used to detect the signal. Analysis was carried out in triplicate.

Table 1. The gene sequence of each primer.

\begin{tabular}{cccc}
\hline Gene Name & Forward Primer & Reverse Primer & Accession No. \\
\hline PPAR $\gamma$ & TTTTCAAGGGTGCCAGTTTC & AATCCTTGGCCCTCTGAGAT & NM_011146 \\
C $/$ EBP $\alpha$ & TTACAACAGGCCAGGTTTCC & GGCTGGCGACATACAGTACA & NM_007678 \\
SREBP1c & ACAGACAAACTGCCCATCCA & GCAAGAAGCGGATGTAGTCG & NM 011480.3 \\
LPL & CATCGAGAGGATCCGAGTGAA & TGCTGAGTCCTTTCCCTTCTG & NM_008509 \\
ap2 & GGCCAAGCCCAACATGATC & CACGCCCAGTTTGAAGGAAA & NM_024406 \\
B-actin & CCACAGCTGAGAGGGAAATC & AAGGAAGGCTGGAAAAGAGC & X03672 \\
\hline
\end{tabular}

\subsection{Statistics}

Values were expressed as the means $\pm \mathrm{SD}$, and all the above assays were repeated at least three times. SPSS (Statistical Package for Social Science) version 17.0 was used to process data by ANOVA and Tukey's test. Cell culture data were analyzed with one-way ANOVA followed by Dunnett's $t$-test to compare treatments with control group.

\section{Results and Discussion}

\subsection{Quality Analysis of Different Common Bean Extracts}

Firstly, we evaluated the quality of the three extracts from white common bean seeds. Phenolic acids and flavonoids are the main polyphenols in common beans, such as rutin, ferulic acid, catechin, chlorogenic acid, coumarin, and genistein [34]. In virtue of the HPLC system, five kinds of phenolic compounds were detected in the CBP, as follows: ferulic acid $(0.31 \pm 0.04 \mathrm{mg} / \mathrm{g}), p$-coumaric acid $(0.12 \pm 0.03 \mathrm{mg} / \mathrm{g})$, sinapic acid $(0.11 \pm 0.02 \mathrm{mg} / \mathrm{g})$, chlorogenic acid $(14.32 \pm 1.45 \mu \mathrm{g} / \mathrm{g})$, and quercetin $(6.46 \pm 0.26 \mu \mathrm{g} / \mathrm{g})$. The total polyphenols content was determined to be $6.57 \pm 0.242 \mathrm{mg}$ GAE/g (Table 2). These results are consistent with our previous study, which estimated that phenolic compounds in white common bean are mainly contain ferulic acid $(26.06 \pm 2.19 \mathrm{mg} / 100 \mathrm{~g}), p$-coumaric acid $(11.10 \pm 0.16 \mathrm{mg} / 100 \mathrm{~g})$, sinapic acid $(9.55 \pm 0.24 \mathrm{mg} / 100 \mathrm{~g})$, and chlorogenic acid $(0.18 \pm 0.05 \mathrm{mg} / 100 \mathrm{~g})$ [27]. The $\alpha$-amylase inhibition activity of $\alpha$-AIE was determined to be $1027.1 \pm 154.2\left(\mathrm{U} \mathrm{mg}^{-1}\right.$ protein). Our previous result showed that the $\alpha$-amylase inhibition activity of $\alpha$-AIE from common bean accessions varied from 613.40 to $1925.58 \mathrm{U} \mathrm{mg}^{-1}$ protein [29]. In this study, NSP was purified by a ÄKTA explore 100 purification system and the purity is $88.37 \%$. The HPSEC-MALLS-RID system analysis exhibited an average molecular weight of NSP that is $6.27 \times 10^{5} \mathrm{Da}$.

Table 2. The essential information of the common bean polyphenol-rich extract (CBP), $\alpha$-amylase inhibitor-rich extract (a-AIE) and non-starch polysaccharides-rich extract (NSP) extracted from white common beans.

\begin{tabular}{|c|c|c|c|c|c|c|c|c|c|}
\hline \multicolumn{6}{|c|}{ CBP } & \multicolumn{2}{|c|}{ a-AIE } & \multicolumn{2}{|c|}{ NSP } \\
\hline $\begin{array}{l}\text { Ferulic } \\
\text { Acid } \\
(\mathrm{mg} / \mathrm{g})\end{array}$ & $\begin{array}{c}\text { p- } \\
\text { Coumaric } \\
\text { Acid } \\
(\mathrm{mg} / \mathrm{g})\end{array}$ & $\begin{array}{l}\text { Sinapic } \\
\text { Acid } \\
(\mathrm{mg} / \mathrm{g})\end{array}$ & $\begin{array}{c}\text { Chlorogenic } \\
\text { Acid } \\
(\mu \mathrm{g} / \mathrm{g})\end{array}$ & $\begin{array}{c}\text { Quercetin } \\
(\mu \mathrm{g} / \mathrm{g})\end{array}$ & $\begin{array}{c}\text { TPC } \\
\text { (mg } \\
\text { GAE/g) }\end{array}$ & $\begin{array}{l}\text { Total } \\
\text { Protein } \\
(\%)\end{array}$ & $\begin{array}{c}\text { Inhibitory } \\
\text { Activity of } \\
\alpha \text {-AIE (U } \\
\text { mg-1 Dry } \\
\text { Weight) }\end{array}$ & Purity (\%) & $\begin{array}{l}\text { Molecular } \\
\text { Weight } \\
\text { (Da) }\end{array}$ \\
\hline $0.31 \pm 0.04$ & $0.12 \pm 0.03$ & $0.11 \pm 0.02$ & $\begin{array}{c}14.32 \pm \\
1.45\end{array}$ & $6.46 \pm 0.26$ & $6.57 \pm 0.24$ & $\begin{array}{c}68.97 \pm \\
2.47\end{array}$ & $\begin{array}{c}1027.1 \pm \\
154.2\end{array}$ & $\begin{array}{c}88.37 \pm \\
2.12\end{array}$ & $6.27 \times 10^{5}$ \\
\hline
\end{tabular}

Data are expressed as mean \pm SD deviation of triplicate samples. 


\subsection{Cell Cytotoxicity Assay}

In order to exclude the effects of nonspecific toxicity on the adipogenesis physiological process, the toxicity of the above extracts was evaluated. The cell proliferation curves in Figure 1 A exhibits that CBP exerts no cytotoxicity at the concentrations less than $300 \mu \mathrm{g} / \mathrm{mL}$. This is supported by the description of Sung et al. that crude polyphenols or flavonoids extracts from mandarin peel show no cytotoxicity on at the dose of $1 \mathrm{mg} / \mathrm{mL}$ [35]. $\alpha$-AIE and NSP also exhibit no cytotoxicity on 3T3-L1 adipocytes at the tested concentrations $(0-4 \mathrm{mg} / \mathrm{mL}$ ) (Figure 1B,C).

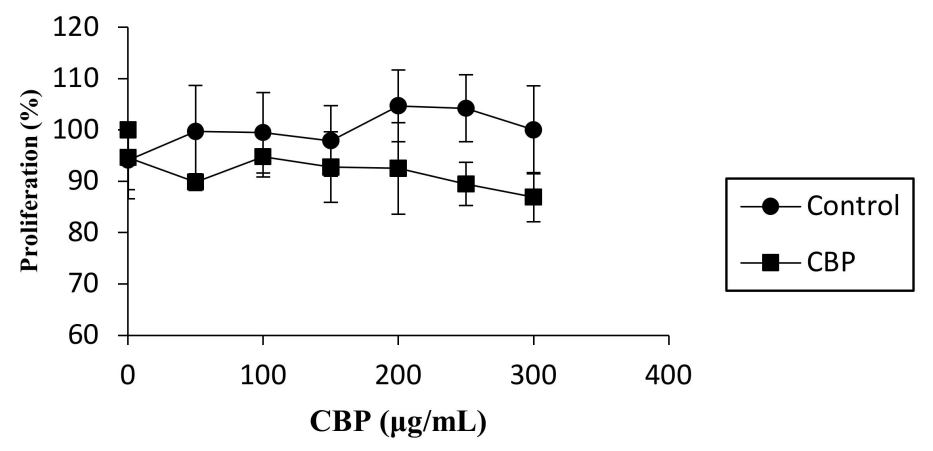

(A)

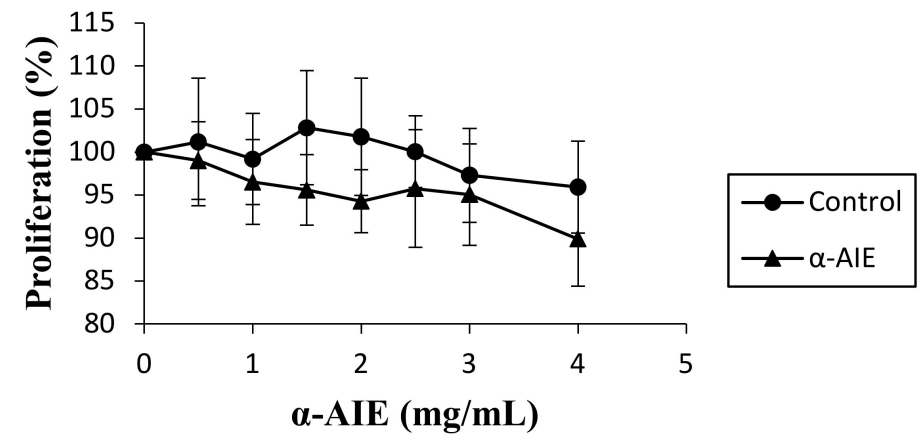

(B)

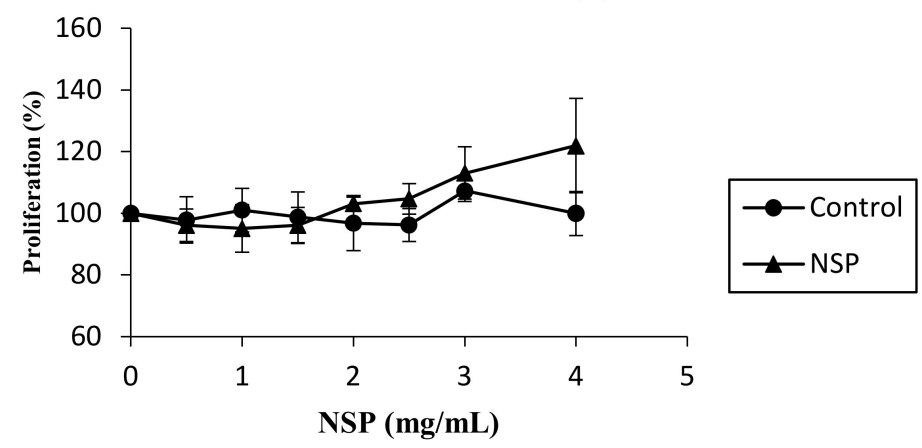

(C)

Figure 1. The cytotoxicity of CBP (A), $\alpha$-AIE (B), and NSP (C). Cultures in basal medium served as control. Three independent experiments were performed, and the data were shown as mean $\pm \mathrm{SD}$. There is no significant difference between the experimental groups and the control group.

\subsection{Intracellular Lipid Accumulation}

A recent in vivo study revealed that the consumption of whole common bean foods reduces the fat mass of obese rats and regulates the expression level of genes implicated in lipid metabolism [15]. In this study, an in vitro experiment was performed to demonstrate the influence of different white common bean bioactive components on lipid accumu- 
lation. As shown (Figure 2A), compared with the adipocyte group, CBP significantly suppresses lipid accumulation in the mature adipocyte, suggesting inhibitory effects on 3T3-L1 adipocyte differentiation. The Optical Density (O.D.) absorbance is reduced to $79.29 \%$ and $35.13 \%$ by $150 \mu \mathrm{g} / \mathrm{mL}$ of CBP and $300 \mu \mathrm{g} / \mathrm{mL}$ of CBP, respectively (Figure $2 \mathrm{~B}$ ). Consistent with our results, Park et al. 2015 reported that the phenolic compound extracts from raspberry show inhibitory effects on the lipid accumulation within a dose from 1 to $50 \mu \mathrm{M}$ in a dose-dependent manner [28]. From the results of phenolic compounds composition analysis, ferulic acid and $p$-coumaric acids are the major phenolic compounds in CBP. In a previous study, the similar inhibitory effects of these two compounds from corn silk extracts on the 3T3-L1 adipocyte differentiation were proven [36]. Aranaz et al. also reported that phenolic acids, including ferulic acid and $p$-coumaric acids, significantly inhibit the differentiation of 3T3-L1 cells due to the binding affinity to PPAR $\gamma$ [37]. These results indicate that $\mathrm{CBP}$ contributes to the anti-obesity effects of common bean foods through inhibiting 3T3-L1 adipocyte differentiation.

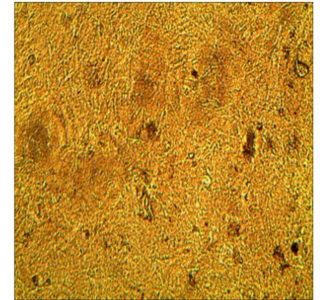

Pre-Adipocyte

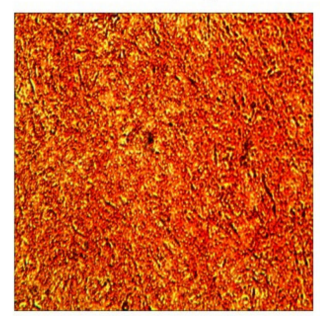

$\alpha$-AIE $(2 \mathrm{mg} / \mathrm{mL})$

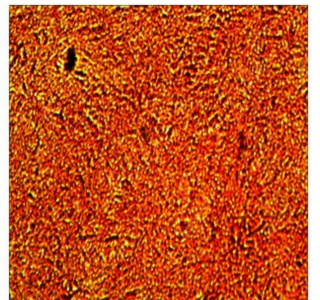

Adipocyte

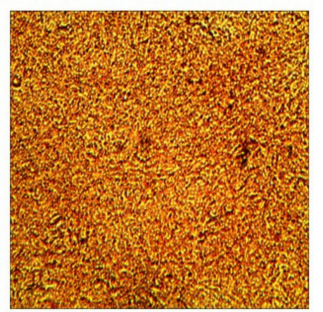

$\alpha$-AIE (4 mg/mL)

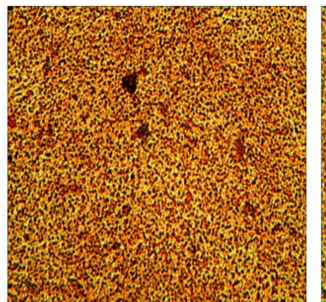

CBP $(150 \mu \mathrm{g} / \mathrm{mL})$

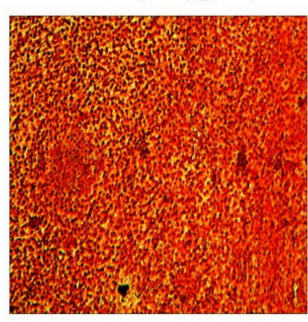

$\mathrm{NSP}(2 \mathrm{mg} / \mathrm{mL})$

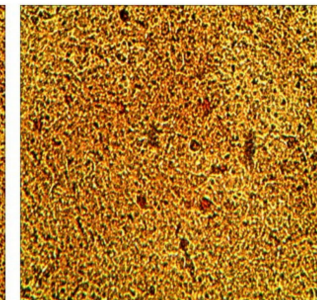

CBP $(300 \mu \mathrm{g} / \mathrm{mL})$

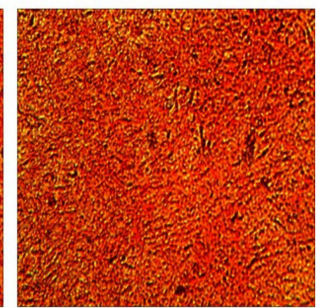

$\mathrm{NSP}(4 \mathrm{mg} / \mathrm{mL})$

(A)

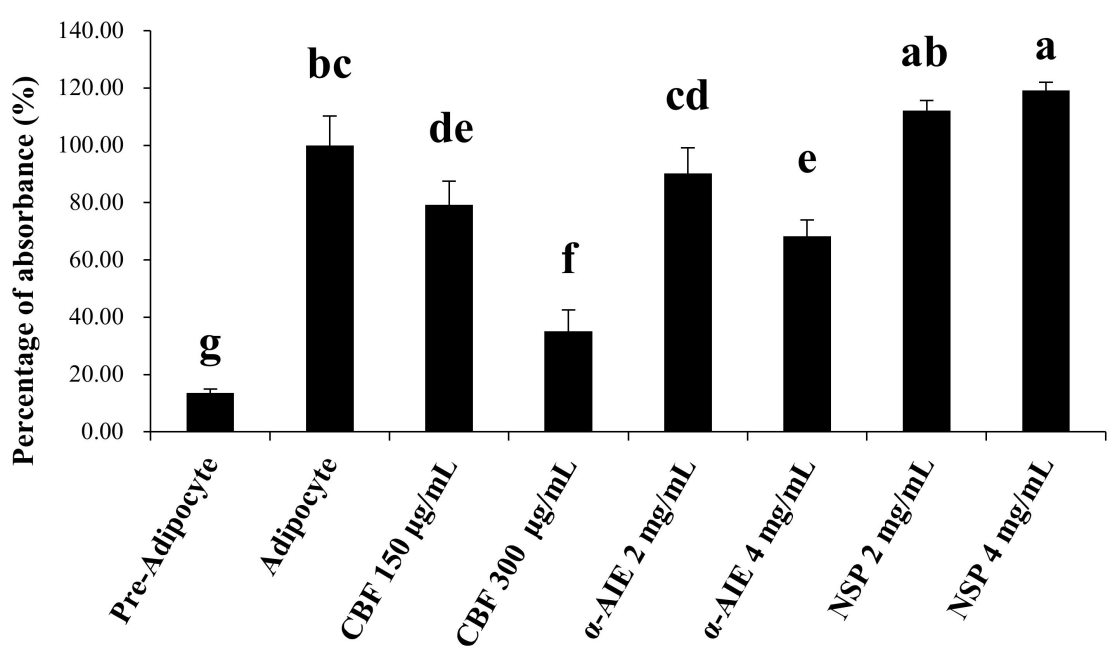

(B)

Figure 2. Effects of CBP, $\alpha$-AIE, and NSP on lipid accumulation in 3T3-L1 cells. (A) Oil red O staining, and (B) Optical Density (O.D.) absorbance value. The data was expressed as mean \pm SD. Different letters mean significantly difference $(p<0.05)$. 
Due to the starch blocker role, $\alpha$-AI is always thought to be the major bioactive component responsible for the anti-obesity effects of common bean foods [38,39]. Our results showed that the $\alpha$-AIE from white common bean inhibits the 3T3-L1 adipocyte differentiation (Figure 2A). The O.D. absorbances are reduced to $90.20 \%$ and $68.28 \%$ by $2 \mathrm{mg} / \mathrm{mL}$ of a-AIE and $4 \mathrm{mg} / \mathrm{mL}$ of a-AIE, respectively (Figure 2B). These results give us a new insight into the mechanism of the anti-obesity effects of a-AI from common bean, except for the inhibition of starch digestion.

Although recent evidence suggested that plants NSP can restrain the adipocyte differentiation $[13,40]$, in this study, the NSP from white common bean displays no inhibitory effects on 3T3-L1 adipocyte differentiation, and it even slightly promotes the lipid accumulation in 3T3-L1 cells (Figure 2A). Compared with the adipocyte group, the O.D. absorbances are increased to $112.12 \%$ and $119.07 \%$ by $2 \mathrm{mg} / \mathrm{mL}$ of NSP and $4 \mathrm{mg} / \mathrm{mL}$ of NSP, respectively (Figure 2B). A similar phenomenon was reported by Zhang et al., who found that the addition of astragalus polysaccharides (ASP) increases lipid accumulation in 3T3-L1 cells after 6 days of differentiation, which may own to the improvement effect of ASP on the insulin sensitivity of cells [41]. Different polysaccharides have different chemical structures, such as molecular weight, monosaccharide composition, and functional groups, which may lead to different bioactivities.

\section{4. $m R N A$ and Protein Expression of PPAR $\gamma, C / E B P \alpha$, and SREBP-1c}

The PPAR $\gamma, \mathrm{C} / \mathrm{EBP} \alpha$, and SREBP1c are sequentially and cooperatively expressed during 3T3-L1 adipocyte differentiation [42]. PPAR $\gamma$ is an essential factor in adipocyte differentiation, which is involved in the regulation of adipocyte lipogenesis. C/EBP $\alpha$ triggers the expression of adipocyte-specific genes together with PPAR $\gamma$. SREBP1c controls fatty acids synthesis during 3T3-L1 adipocytes differentiation [34,35]. In the present study, we investigated whether the reduced intracellular lipid contents were related to the decreased expression of these transcription factors. The results of the RT-PCR analysis and Western blot analysis demonstrated that CBP and $\alpha$-AIE suppress the mRNA expression level and protein expression level of PPAR $\gamma, \mathrm{C} / \mathrm{EBP} \alpha$, and SREBP-1c, in a dose-dependent manner (Figures 3 and 4 ). No statistical significances $(p<0.05)$ are found in a low dose of $\alpha$-AIE $(2 \mathrm{mg} / \mathrm{mL})$. PPAR $\gamma, \mathrm{C} / \mathrm{EBP} \alpha$, and SREBP1c are early expressed in adipocyte differentiation. Our results suggest that CBP and $\alpha$-AIE inhibit the adipogenesis of 3T3-L1 adipocytes at an early stage of adipogenesis, and CBP exhibits stronger effects than $\alpha$-AIE.

LPL and ap2 are the downstream regulatory factors of DNA in the process of adipogenesis and are specific genes in adipose tissue that are jointly activated by PPAR $\gamma$ and $\mathrm{C} / \mathrm{EBP} \alpha$ during fatty acid metabolism [43]. Since the inhibitory effects of CBP and $\alpha$-AIE on the mRNA and protein expression of PPAR $\gamma$ and $\mathrm{C} / \mathrm{EBP} \alpha$ were demonstrated, we next evaluated their effects on the expression of ap2 and LPL. Excess aP2 secreted from adipose tissue acts as a hormone, supporting inter-organ communication and resulting in lipid derangement [44]. As shown (Figure 3), mRNA expression levels of ap2 are significantly $(p<0.05)$ downregulated to $82.69 \%$ and $66.52 \%$ by different doses of CBP $(150 \mu \mathrm{g} / \mathrm{mL}$ and $300 \mu \mathrm{g} / \mathrm{mL}$ ). However, the obvious inhibition in the expression of ap2 was only observed for a high dose of $\alpha$-AIE ( $4 \mathrm{mg} / \mathrm{mL})$. Excess fatty acids can enter into white fat cells under the action of LPL and be stored after esterification, and it may tend to obese [37]. Results showed that CBP also significantly $(p<0.05)$ reduces the mRNA expression levels of LPL to $87.57 \%$ and $72.77 \%$, while $\alpha$-AIE has no statistically effect on it. The Western blot results show that the LPL and ap2 protein expression levels are consistent with mRNA expression and show a similar trend (Figure 4). These results further demonstrate that CBP showed better inhibitory effects on adipocyte differentiation than $\alpha$-AIE. 

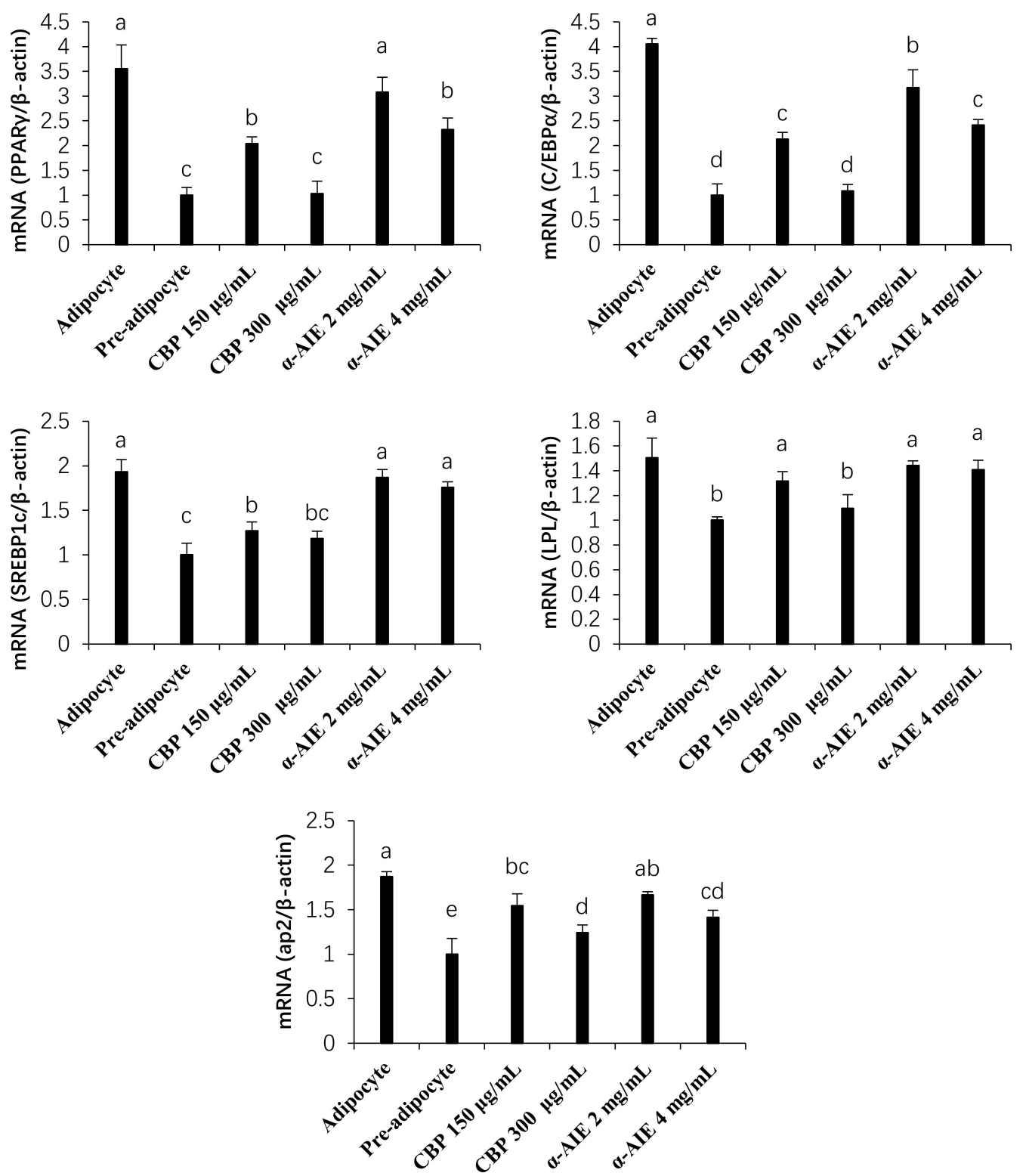

Figure 3. Effects of CBP and $\alpha$-AIE on the mRNA expression level of peroxisome-proliferator-activated receptor families $(\mathrm{PPAR} \gamma), \mathrm{CCAAT} /$ enhancer binding protein $(\mathrm{C} / \mathrm{EBP} \alpha)$, sterol-regulatory element binding proteins $1 \mathrm{c}(\mathrm{SREBP} 1 \mathrm{c})$, lipoprotein lipase (LPL), and astragalus polysaccharides (ap2). The data were expressed as mean $\pm \mathrm{SD}$. Different letters mean significantly different $(p<0.05)$.
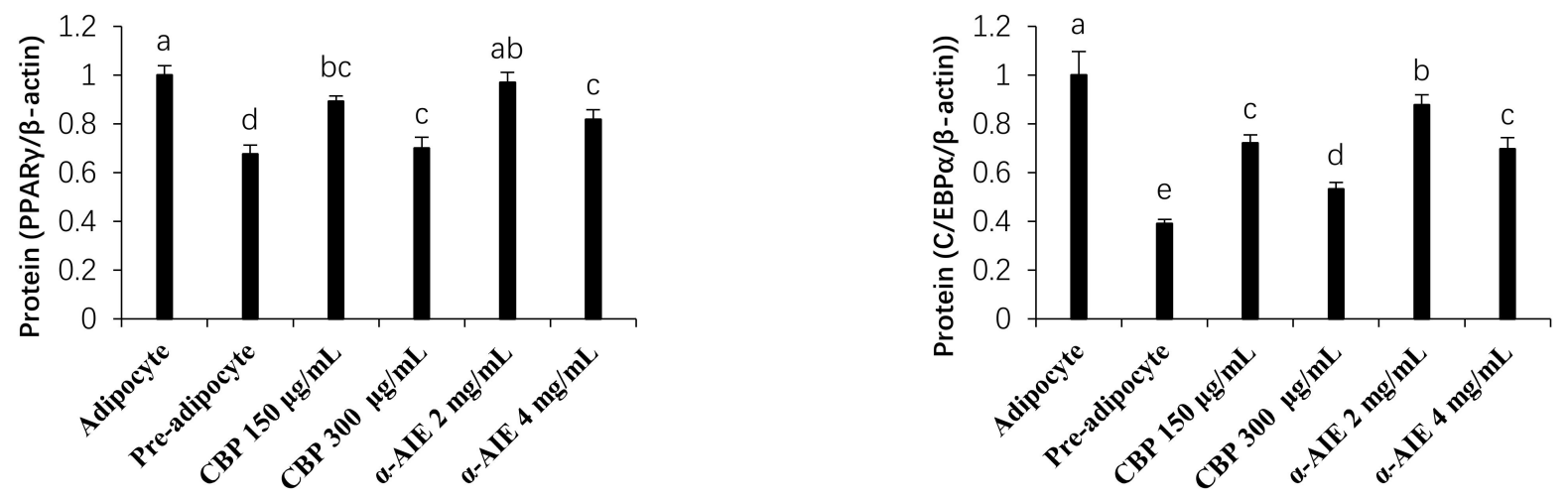

Figure 4. Cont. 

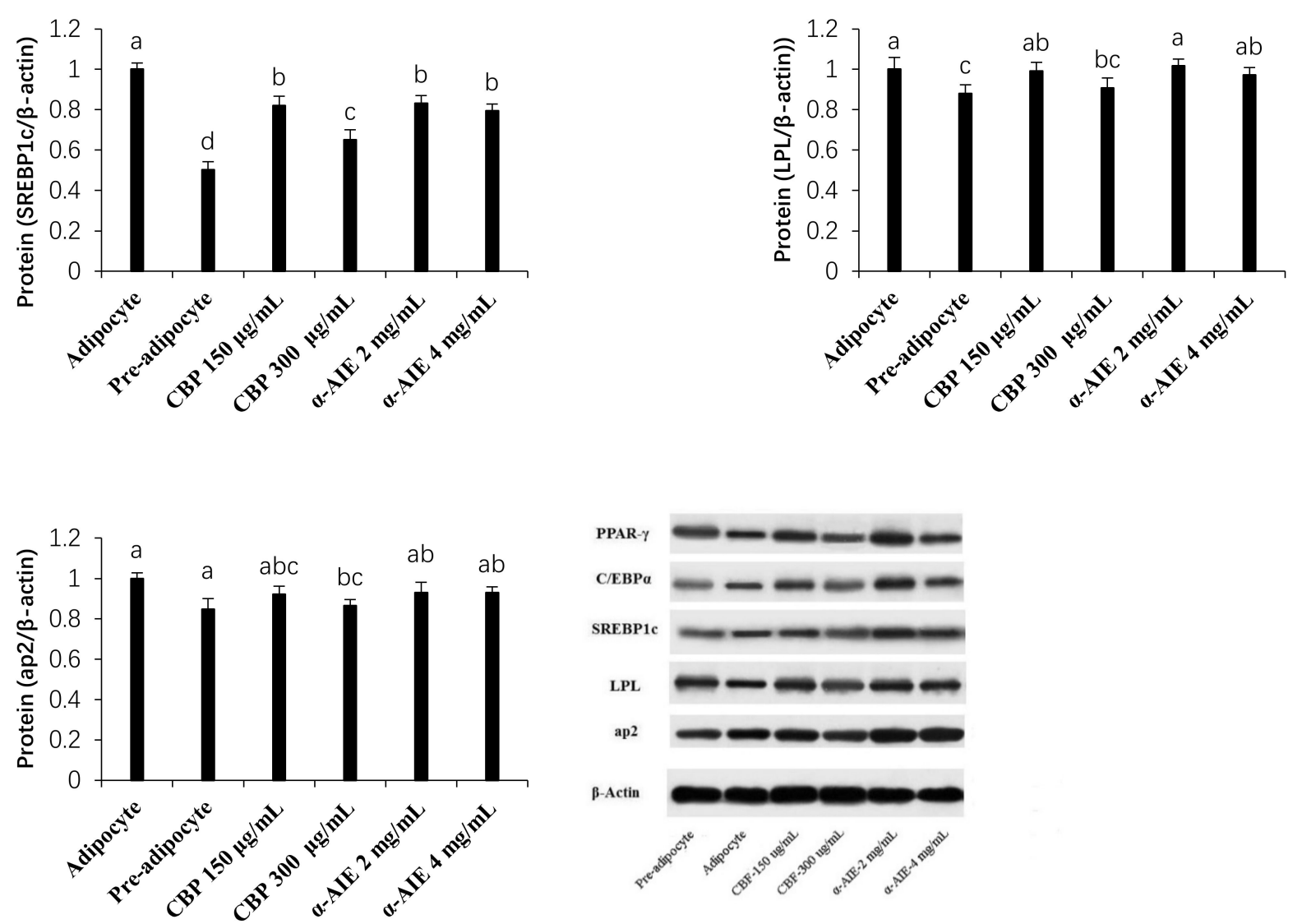

Figure 4. Effects of CBP and $\alpha$-AIE on the protein expression level of PPAR $\gamma, \mathrm{C} / \mathrm{EBP} \alpha, \mathrm{SREBP} 1 \mathrm{c}, \mathrm{LPL}$, and ap2. The data were expressed as mean \pm SD. Different letters mean significantly different $(p<0.05)$.

\section{5. $m R N A$ and Protein Expression of LPL and ap2}

\section{Conclusions}

In conclusion, among the three tested natural extracts from white common bean, CBP and $\alpha$-AIE inhibit 3T3-L1 adipocytes differentiation evidenced by the results of Oil red $\mathrm{O}$ staining. In addition, CBP and $\alpha$-AIE downregulate the mRNA and protein expression level of PPAR $\gamma, \mathrm{C} / \mathrm{EBP} \alpha, \mathrm{SREBP}-1 \mathrm{c}$, ap2, and LPL. However, CBP shows stronger inhibitory effects and $\alpha$-AIE only show a slight inhibition. These findings indicate that CBP, from white common bean, might be the major component responsible for the inhibitory effects on adipocyte differentiation in vitro.

Author Contributions: Conceptualization, Z.S., Y.Z. and Y.Y.; Methodology, Z.S.; Software, Z.S., X.Z.; Validation, G.R.; Formal Analysis, G.R.; Investigation, X.Z., Z.S. and Y.Y.; Resources, G.R.; Data Curation, Z.S. and Y.Z.; Writing-Original Draft Preparation, Z.S.; Writing-Review and Editing, X.Z., Y.Z. and Y.Y.; Supervision, G.R.; Project Administration, G.R. and Y.Y.; Funding Acquisition, X.Z. and G.R. All authors have read and agreed to the published version of the manuscript.

Funding: This research received no external funding.

Institutional Review Board Statement: Not applicable.

Informed Consent Statement: Not applicable.

Data Availability Statement: Data available in a publicly accessible repository.

Acknowledgments: The present study was supported by the earmarked fund for the National Natural Science Foundation of China (31571737). This work was supported by the earmarked fund for the Modern Agro-industry Technology Research System (CARS-08-G20) and China Agriculture Research System (31701597). We also thank for the support of China Scholarship Council (CSC) and National Crop Germplasm Resources Center. 
Conflicts of Interest: The authors have no conflict of interest with others.

\section{References}

1. Chooi, Y.C.; Ding, C.; Magkos, F. The epidemiology of obesity. Metabolism 2019, 92, 6-10. [CrossRef] [PubMed]

2. Masa, J.F.; Pépin, J.-L.; Borel, J.-C.; Mokhlesi, B.; Murphy, P.B.; Sánchez-Quiroga, M.Á. Obesity hypoventilation syndrome. Eur. Respir. Rev. 2019, 28, 151. [CrossRef] [PubMed]

3. Zhang, J.; Wang, H.; Wang, Z.; Du, W.; Su, C.; Zhang, J.; Jiang, H.; Jia, X.; Huang, F.; Ouyang, Y. Prevalence and stabilizing trends in overweight and obesity among children and adolescents in China, 2011-2015. BMC Public Health 2018, 18, 571. [CrossRef]

4. Blüher, M. Obesity: Global epidemiology and pathogenesis. Nat. Rev. Endocrinol. 2019, 15, 288. [CrossRef]

5. Fu, Y.; Luo, N.; Klein, R.L.; Garvey, W.T. Adiponectin promotes adipocyte differentiation, insulin sensitivity, and lipid accumulation. J. Lipid Res. 2005, 46, 1369-1379. [CrossRef] [PubMed]

6. Zhang, X.; Chen, X.; Kong, Q.; Cheng, H.; Cao, X.; Li, Y.; Li, C.; Liu, L.; Ding, Z. HSPA12A is required for adipocyte differentiation and diet-induced obesity through a positive feedback regulation with PPAR $\gamma$. Cell Death Differ. 2019, 26, 2253-2267. [CrossRef]

7. Siraj, F.M.; SathishKumar, N.; Kim, Y.J.; Kim, S.Y.; Yang, D.C. Ginsenoside F2 possesses anti-obesity activity via binding with PPAR $\gamma$ and inhibiting adipocyte differentiation in the 3T3-L1 cell line. J. Enzyme Inhib. Med. Chem. 2015, 30, 9-14. [CrossRef]

8. Kim, M.; Park, J.-E.; Song, S.-B.; Cha, Y.-S. Effects of black adzuki bean (Vigna angularis) extract on proliferation and differentiation of 3T3-L1 preadipocytes into mature adipocytes. Nutrients 2015, 7, 277-292. [CrossRef]

9. Tutunchi, H.; Saghafi-Asl, M.; Ostadrahimi, A. A systematic review of the effects of oleoylethanolamide, a high-affinity endogenous ligand of PPAR- $\alpha$, on the management and prevention of obesity. Clin. Exp. Pharmacol. Physiol. 2020, 47, 543-552. [CrossRef]

10. Zingue, S.; do Carmo, Í.A.R.; Tchoumtchoua, J.; Tchoupang, E.N.; de Oliveira Souza Bratti, L.; Dal Mora, T.; Halabalaki, M.; Njamen, D.; Creczynski-Pasa, T.B.; Filippin-Monteiro, F.B. Millettia macrophylla (Fabaceae) phenolic fraction prevents differentiation of 3T3-L1 adipocytes and the increased risks of cardiovascular diseases in ovariectomized rats. J. Ethnopharmacol. 2018, 222, 87-98. [CrossRef]

11. Zhu, H.; Ding, H.; Deng, J.; Pan, H.; Wang, L.; Li, N.; Wang, X.; Shi, Y.; Gong, F. Inhibition of preadipocyte differentiation and adipogenesis by zinc- $\alpha 2$-glycoprotein treatment in 3T3-L1 cells. J. Diabetes Investig. 2013, 4, 252-260. [CrossRef]

12. Toledo, M.E.O.; de Mejia, E.G.; Sivaguru, M.; Amaya-Llano, S.L. Common bean (Phaseolus vulgaris L.) protein-derived peptides increased insulin secretion, inhibited lipid accumulation, increased glucose uptake and reduced the phosphatase and tensin homologue activation in vitro. J. Funct. Foods 2016, 27, 160-177. [CrossRef]

13. Zhu, Y.; Yao, Y.; Gao, Y.; Hu, Y.; Shi, Z.; Ren, G. Suppressive Effects of Barley $\beta$-Glucans with Different Molecular Weight on 3T3-L1 Adipocyte Differentiation. J. Food Sci. 2016, 81, H786-H793. [CrossRef] [PubMed]

14. Singh, S.P.; Gepts, P.; Debouck, D.G. Races of common bean (Phaseolus vulgaris, Fabaceae). Econ. Bot. 1991, 45, 379-396. [CrossRef]

15. Thompson, H.; McGinley, J.; Neil, E.; Brick, M. Beneficial effects of common bean on adiposity and lipid metabolism. Nutrients 2017, 9, 998. [CrossRef] [PubMed]

16. Neil, E.S.; McGinley, J.N.; Fitzgerald, V.K.; Lauck, C.A.; Tabke, J.A.; Streeter-McDonald, M.R.; Yao, L.; Broeckling, C.D.; Weir, T.L.; Foster, M.T. White Kidney Bean (Phaseolus vulgaris L.) Consumption Reduces Fat Accumulation in a Polygenic Mouse Model of Obesity. Nutrients 2019, 11, 2780. [CrossRef]

17. Bouchenak, M.; Lamri-Senhadji, M. Nutritional quality of legumes, and their role in cardiometabolic risk prevention: A review. J. Med. Food 2013, 16, 185-198. [CrossRef]

18. Guevara, M.; Tejera, E.; Granda-Albuja, M.G.; Iturralde, G.; Chisaguano-Tonato, M.; Granda-Albuja, S.; Jaramillo-Vivanco, T.; Giampieri, F.; Battino, M.; Alvarez-Suarez, J.M. Chemical composition and antioxidant activity of the main fruits consumed in the western coastal region of Ecuador as a source of health-promoting compounds. Antioxidants 2019, 8, 387. [CrossRef]

19. Layer, P.; Carlson, G.L.; Dimagno, E.P. Partially purified white bean amylase inhibitor reduces starch digestion in vitro and inactivates intraduodenal amylase in humans. Gastroenterology 1985, 88, 1895-1902. [CrossRef]

20. Shi, Z.; Zhu, Y.; Teng, C.; Yao, Y.; Ren, G.; Richel, A. Anti-obesity effects of $\alpha$-amylase inhibitor enriched-extract from white common beans (Phaseolus vulgaris L.) associated with the modulation of gut microbiota composition in high-fat diet-induced obese rats. Food Funct. 2020, 11, 1624-1634. [CrossRef]

21. Choi, J.W.; Synytsya, A.; Capek, P.; Bleha, R.; Pohl, R.; Park, Y. Il Structural analysis and anti-obesity effect of a pectic polysaccharide isolated from Korean mulberry fruit Oddi (Morus alba L.). Carbohydr. Polym. 2016, 146, 187-196. [CrossRef] [PubMed]

22. Lao, W.W. Targeting Cellurlar Dysfunction with Green Tea Polyphenols to Treat the Underlying Basis of the Metabolic Complications of Obesity. Ph.D. Thesis, School of Life Sciences, University of Technology Sydney, Sydney, Australia, 2018.

23. Kim, N.-H.; Jegal, J.; Kim, Y.N.; Heo, J.-D.; Rho, J.-R.; Yang, M.H.; Jeong, E.J. Chokeberry extract and its active polyphenols suppress adipogenesis in 3T3-L1 adipocytes and modulates fat accumulation and insulin resistance in diet-induced obese mice. Nutrients 2018, 10, 1734. [CrossRef]

24. Liu, H.; Wang, J.; Liu, M.; Zhao, H.; Yaqoob, S.; Zheng, M.; Cai, D.; Liu, J. Antiobesity effects of ginsenoside Rg1 on 3T3-L1 preadipocytes and high fat diet-induced obese mice mediated by AMPK. Nutrients 2018, 10, 830. [CrossRef] [PubMed]

25. Gao, Y.; Yao, Y.; Zhu, Y.; Ren, G. Isoflavones in Chickpeas Inhibit Adipocyte Differentiation and Prevent Insulin Resistance in 3T3-L1 Cells. J. Agric. Food Chem. 2015, 63, 9696-9703. [CrossRef] [PubMed]

26. Shi, Z.; Yao, Y.; Zhu, Y.; Ren, G. Nutritional composition and biological activities of 17 Chinese adzuki bean (Vigna angularis) varieties. Food Agric. Immunol. 2017, 28, 78-89. [CrossRef] 
27. Yao, Y.; Cheng, X.; Wang, L.; Wang, S.; Ren, G. Biological potential of sixteen legumes in China. Int. J. Mol. Sci. 2011, 12, 7048-7058. [CrossRef]

28. Wang, H.H.; Chen, C.L.; Jeng, T.L.; Sung, J.M. Comparisons of $\alpha$-amylase inhibitors from seeds of common bean mutants extracted through three phase partitioning. Food Chem. 2011, 128, 1066-1071. [CrossRef]

29. Yao, Y.; Hu, Y.; Zhu, Y.; Gao, Y.; Ren, G. Comparisons of phaseolin type and $\alpha$-amylase inhibitor in common bean (Phaseolus vulgaris L.) in China. Crop J. 2016, 4, 68-72. [CrossRef]

30. Zhang, Y.; Zhang, L.; Yang, J.; Liang, Z. Structure analysis of water-soluble polysaccharide CPPS3 isolated from Codonopsis pilosula. Fitoterapia 2010, 81, 157-161. [CrossRef]

31. Yao, Y.; Xue, P.; Zhu, Y.; Gao, Y.; Ren, G. Antioxidant and immunoregulatory activity of polysaccharides from adzuki beans (Vigna angularis). Food Res. Int. 2015, 77, 251-256. [CrossRef]

32. Jiang, X.; Li, T.; Liu, R.H. 2 $\alpha$-Hydroxyursolic acid inhibited cell proliferation and induced apoptosis in MDA-MB-231 human breast cancer cells through the p38/MAPK signal transduction pathway. J. Agric. Food Chem. 2016, 64, 1806-1816. [CrossRef] [PubMed]

33. Kowalska, K.; Olejnik, A.; Rychlik, J.; Grajek, W. Cranberries (Oxycoccus quadripetalus) inhibit lipid metabolism and modulate leptin and adiponectin secretion in 3T3-L1 adipocytes. Food Chem. 2015, 185, 383-388. [CrossRef] [PubMed]

34. Yang, Q.-Q.; Gan, R.-Y.; Ge, Y.-Y.; Zhang, D.; Corke, H. Ultrasonic treatment increases extraction rate of common bean (Phaseolus vulgaris L.) antioxidants. Antioxidants 2019, 8, 83. [CrossRef] [PubMed]

35. Sung, J.; Suh, J.H.; Wang, Y. Effects of heat treatment of mandarin peel on flavonoid profiles and lipid accumulation in 3T3-L1 adipocytes. J. Food Drug Anal. 2019, 27, 729-735. [CrossRef]

36. Chaiittianan, R.; Chayopas, P.; Rattanathongkom, A.; Tippayawat, P.; Sutthanut, K. Anti-obesity potential of corn silks: Relationships of phytochemicals and antioxidation, anti-pre-adipocyte proliferation, anti-adipogenesis, and lipolysis induction. J. Funct. Foods 2016, 23, 497-510. [CrossRef]

37. Aranaz, P.; Navarro-Herrera, D.; Zabala, M.; Miguéliz, I.; Romo-Hualde, A.; López-Yoldi, M.; Alfredo Martínez, J.; Vizmanos, J.L.; Milagro, F.I.; González-Navarro, C.J. Phenolic compounds inhibit 3T3-L1 adipogenesis depending on the stage of differentiation and their binding affinity to PPAR $\gamma$. Molecules 2019, 24, 1045. [CrossRef]

38. Santimone, M.; Koukiekolo, R.; Moreau, Y.; Le Berre, V.; Rougé, P.; Marchis-Mouren, G.; Desseaux, V. Porcine pancreatic $\alpha$-amylase inhibition by the kidney bean (Phaseolus vulgaris) inhibitor ( $\alpha$-AI1) and structural changes in the $\alpha$-amylase inhibitor complex. Biochim. Biophys. Acta (BBA)-Proteins Proteomics 2004, 1696, 181-190. [CrossRef]

39. Zou, W.; Schulz, B.L.; Tan, X.; Sissons, M.; Warren, F.J.; Gidley, M.J.; Gilbert, R.G. The role of thermostable proteinaceous $\alpha$-amylase inhibitors in slowing starch digestion in pasta. Food Hydrocoll. 2019, 90, 241-247. [CrossRef]

40. Liu, J.L.; Yang, L.C.; Zhu, X.J.; Wang, W.J.; Zheng, G.D. Combinational effect of pine needle polysaccharide and kudzu flavonoids on cell differentiation and fat metabolism in 3T3-L1 cells. Food Sci. Technol. Res. 2018, 24, 903-910. [CrossRef]

41. Zhang, R.; Qin, X.; Zhang, T.; Li, Q.; Zhang, J.; Zhao, J. Astragalus polysaccharide improves insulin sensitivity via AMPK activation in 3T3-L1 Adipocytes. Molecules 2018, 23, 2711. [CrossRef]

42. Hadrich, F.; Sayadi, S. Apigetrin inhibits adipogenesis in 3T3-L1 cells by downregulating PPAR $\gamma$ and CEBP- $\alpha$. Lipids Health Dis. 2018, 17, 1-8. [CrossRef] [PubMed]

43. Tung, E.W.Y.; Ahmed, S.; Peshdary, V.; Atlas, E. Firemaster ${ }^{\circledR} 550$ and its components isopropylated triphenyl phosphate and triphenyl phosphate enhance adipogenesis and transcriptional activity of peroxisome proliferator activated receptor (Ppar $\gamma$ ) on the adipocyte protein 2 (aP2) promoter. PLoS ONE 2017, 12, e0175855. [CrossRef] [PubMed]

44. Burak, M.F.; Dagtekin, N.; Bejo, P.; Vaillancourt, E.; Liu, L.; Gorgun, C.; Rimm, E.; Tuncman, G.; Hotamisligil, G. OR01-1 Leveraging Immunometabolic Control to Prevent and Treat Obesity Related Asthma. J. Endocr. Soc. 2019, 3, OR01-1. [CrossRef] 